\section{God langtidsbeskyttelse av BCG-vaksine}

BCG-vaksinen kan halvere risikoen for tuberkulose i en 40-årsperiode etter vaksinering. Funnene i studien tyder på at vaksinen er mer kostnadseffektiv enn tidligere antatt.

Folkehelseinstituttet og London School of Hygiene and Tropical Medicine har samarbeidet om en retrospektiv kohortstudie basert på norske data fra den siste runden av skjermbildefotografering i Norge i perioden 1962-75 (1).

Personer i alderen 15-50 år som ikke tidligere var blitt vaksinert eller ikke påvist smittet med tuberkulose ved en positiv tuberkulintest, var kandidater for vaksinering. Studien omfattet nesten 300000 personer som ble vaksinert, og over 80000 som ikke ble vaksinert. Dataene ble koblet til Tuberkuloseregisteret og Folkeregisteret, og alle personene ble fulgt inntil de ble meldt med tuberkulose, døde, utvandret eller til utgangen av 2011. Folketellingsdata fra 1960 og 1970 ble også koblet for å vurdere konfunderende faktorer.

Median oppfølgingstid var 44 år for vaksinerte og 41 år for uvaksinerte. 260 tuberkulosetilfeller ble meldt, med en rate på 1,3 per 100000 personår hos vaksinerte og 3,3 hos uvaksinerte. Justert vaksineeffekt for hele 40-årsperioden var $49 \%$ (95\% KI $26-65)$. Vaksineeffekten var $61 \%, 58 \%$, $38 \%$ og $42 \%$ for henholdsvis årene 0-9 år, 10-19 år, 20-29 år og 30-40 år. Effekten var litt høyere for lungetuberkulose enn for all tuberkulose.

- Denne studien bekrefter den høye beskyttelsen av BCG-vaksinen som er funnet i tidligere studier, sier medforfatter Einar Heldal fra Folkehelseinstituttet. - Funnene tyder også på en effekt 20-40 år etter vaksinering, men effekten er ikke statistisk signifikant, antakelig fordi antallet pasienter er så lavt i begge grupper. Personer inntil 50-årsalderen ble inkludert i studien, men antallet tuberkulosetilfeller var for lavt til å kunne analysere effekten separat i forskjellige aldersgrupper. Studien viser at Skjermbilderegisteret og Tuberkuloseregisteret inneholder forskningsdata av stor internasjonal interesse. Det er viktig å sikre fortsatt høy kvalitet i disse registrene, sier han.

\section{Forskningsgruppe på tvers av land} Ibrahim Abubakar ved University College London jobbet med en systematisk gjennomgang av varigheten av effekten av BCG-vaksinen, og han kontaktet Folkehelseinstituttet

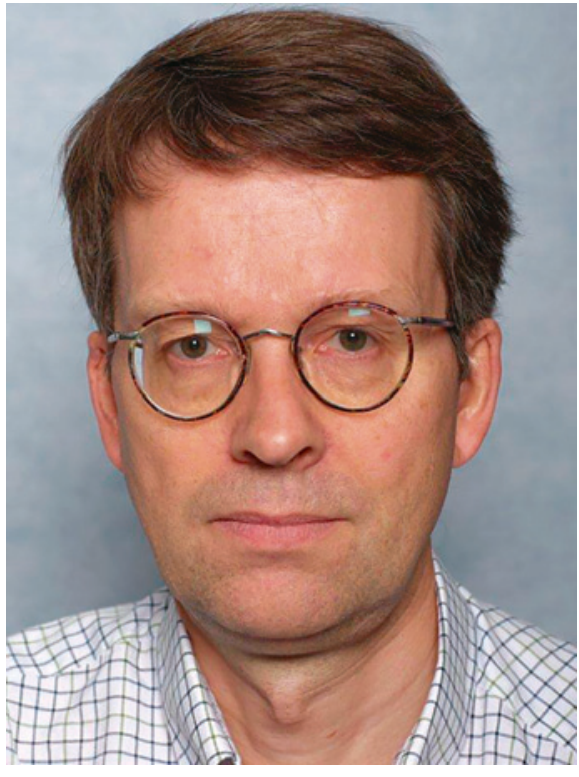

Einar Heldal, Folkehelseinstituttet. Foto: Privat

i Norge da han hørte om norske screeningdata med BCG-status i 1970-årene som kunne kobles til Tuberkuloseregisteret. Han tok også med seg to vaksineeksperter ved London School of Hygiene and Tropical Medicine og en doktorgradsstudent i studien. Ved Avdeling for infeksjonsovervåking hos Folkehelseinstituttet hadde Einar Heldal tidligere brukt registrene til sin doktorgradsavhandling om tuberkuloseepidemiologi.

\section{Kaveh Rashidi}

Tidsskriftet

\section{Litteratur}

1. Nguipdop-Djomo P. Heldal E, Rodrigues LC et al. Duration of BCG protection against tuberculosis and change in effectiveness with time since vaccination in Norway: a retrospective populationbased cohort study. Lancet Infect Dis 2016; 16: $219-26$.
Ordforklaringer

BCG (Bacille Calmette Guerin): Vaksinen gis til personer som ikke er smittet av tuberkulose, for å redusere risikoen for å utvikle sykdom ved smitte.

Vaksineeffekt: I studien beregner man i en Cox regresjonsanalyse hasardratio, som er et statistisk mål for å estimere den relative sannsynligheten for tuberkulose mellom gruppene av vaksinerte og uvaksinerte, over tid. Vaksineeffekten er én minus hasardratio.

Tuberkulose: Tuberkuløs sykdom som skyldes bakterien Mycobacterium tuberculosis. Den spres ved luftsmitte via hosting og nysing fra en person med lungetuberkulose til en annen, som regel en nærkontakt.

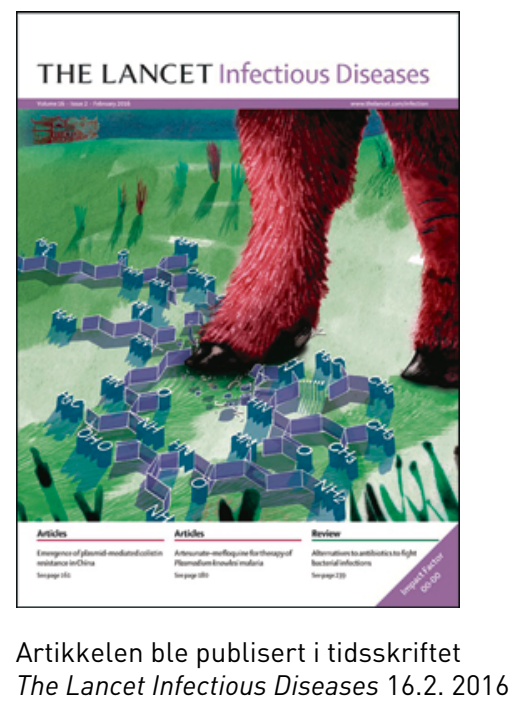

